\title{
Factors that Influence Surplus Underwriting of Tabarru Funds in General Islamic Insurance Companies
}

\section{Mohammad Firdaus Ramdhani P and Puji Sucia Sukmaningrum}

Department of Islamic Economics, Faculty of Economics and Business, Universitas Airlangga

\section{Abstract}

This study aims to determine the effect of participants' contributions, claims, net investment income, and retakaful to surplus underwriting in general insurance of sharia in Indonesia. Selection of sample using purposive sampling method which amounted to eight sharia companies. The data used are monthly in the five year observation period, 2012 until 2016. The approach used is a quantitative approach with panel data regression analysis and using Eviews 9 software. The results showed that the contribution variable of participants and net investment income had positive and

Corresponding Author:

Mohammad Firdaus Ramdhani P mohammad.firdaus-

13@feb.unair.ac.id

Received: 10 February 2019

Accepted: 14 March 2019

Published: 28 March 2019

Publishing services provided by Knowledge E

(c) Mohammad Firdaus

Ramdhani $\mathrm{P}$ and Puji Sucia

Sukmaningrum. This article is

distributed under the terms of

the Creative Commons.

Attribution License, which

permits unrestricted use and

redistribution provided that the

original author and source are credited.

Selection and Peer-review under the responsibility of the ICIEBP Conference Committee.

\section{G OPEN ACCESS} significant effect on the surplus underwriting variable, while the claim variable had a significant negative effect on the surplus underwriting. Meanwhile, the retakaful variable has no significant effect on surplus underwriting

Keywords: participants' contributions, claims, net investment income, retakaful, and surplus underwriting

\section{Introduction}

Islamic insurance is no longer a new thing in the economy in Indonesia. The emergence of various sharia-based financial institutions is now becoming a contemporary phenomenon that gives its own color in the Indonesian economy. After starting with the banking world that applies sharia principles and arguably develops quite rapidly, it is now the turn of the Islamic insurance industry to apply sharia principles to its operations. With knowledge of Islamic banks that first applied sharia principles, it made the wider community more interested in learning it and applying it in economic life. This is supported by Indonesia as the- most Muslim population in the world; it will easily be able to make Islamic insurance grow rapidly. Supported by existing information disclosure and ease of access, the public can easily recognize insurance through television, radio, and print media or by using the internet. 
In this life, without realizing the many threats and dangers that surround us, which is usually called risk, everyone will definitely experience both heavy and light risks. However, often the efforts made are inadequate so as to create a need for a mechanism that is able to share risks such as those offered by Islamic insurance.

Insurance can be carried out by various parties including insurance participants as providers of funds, insurance providers as participants in fund management of participants, companies and halal business units as parties who receive investment from most funds. Islamic insurance is an important requirement and should be fulfilled by every individual who already has income. Because in the individual has a large economic value, so this insurance is responsible for protecting one's economic value.

In Law No. 2 of 1992, it is explained about the meaning of insurance business.

"Insurance or Coverage is an agreement between two or more parties, whereby the insurer binds itself with the insured, by accepting an insurance premium, to provide a replacement to the insured because of loss, damage or loss of expected profits, or legal liability to possible third parties suffered by the insured, arising from an uncertain event, or for payment based on the death or life of the insured person."

Islamic insurance is also called ta'awun insurance which means help each other. Therefore, it can be said that the basic principle of ta'awun insurance is the basis of the Shari'a which is mutually tolerant of fellow human beings to establish togetherness in alleviating disasters experienced by participants.

Islamic insurance is based on the principle of help that is carried out by insurance participants by providing charity funds in the form of tabarru funds. The effort to help each other and work together is then used as one of the bases in the implementation of Islamic insurance practices.

The principle of helping this is the one that complies with the word of Allah SWT in the verse Al Maidah verse 2 :

yā ayyuhallażīna āmanū lā tuhillū sya'ā'irallāhi wa lasy-syahral-ḥarāma wa lal-hadya wa lal-qalā'ida wa lā āmminal-baital-ḥarāma yabtagūna faḍlam mir rabbihim wa rị̣wānā, wa iżā halaltum faștādū, wa lā yajrimannakum syana'ānu qaumin an șaddūkum 'anil-masjidilharāmi an ta'tadū, wa ta'āwanū 'alal-birri wat-taqwā wa lā ta'āwanū 'alal-ismi wal-'udwāni wattaqullāh, innallāha syadidul-'iqāb

"O you who have believed, do not violate the rites of Allah or [the sanctity of] the sacred month or [neglect the marking of] the sacrificial animals and garlanding [them] or [violate the safety of] those coming to the Sacred House seeking bounty from their 
Lord and [His] approval. But when you come out of ihram, then [you may] hunt. And do not let the hatred of a people for having obstructed you from al-Masjid al-Haram lead you to transgress. And cooperate in righteousness and piety, but do not cooperate in sin and aggression. And fear Allah; indeed, Allah is severe in penalty. (Ministry of Religion,2005).

The above verse tells us to help each other help each other in doing good and piety. As if to give a recommendation that always pay attention to well-being (in this case economically) that is good and does not leave difficulties economically, it seems that the Qur'an has long been inviting its people to always pay attention to welfare, one way is to insure.

Tabarru fund management participants in Islamic insurance companies conduct investment activities in accordance with Islamic law. Islamic insurance companies may only invest funds in Islamic financial institutions such as Islamic banks, Islamic bonds, BPRS (Sharia Rural Bank), and other activities that are in accordance with sharia principles. Later from the investment result, the Takaful party will get a profit that will later be entered into the Tabarru fund account. Therefore, the Islamic insurance must be very clever in choosing a sharia financial institution that thinks it generates a large profit in its investment.

Based on the type of risk borne by Islamic insurance, Islamic insurance is divided into two, namely family takaful (life insurance) and general takaful (general insurance) (Rahman, 2011). Family takaful is a form of takaful which provides protection in the face of death and accidents on takaful participants. General takaful is a form of takaful or cooperation that provides protection in the face of disasters and accidents on property of takaful participants.

With insurance can provide peace and ease in business, because with us having insurance no longer need to be anxious to face the risks that will come in the future, and also make it easier for us to deal with problems if a disaster suddenly occurs we are not worried with the risk, or even a loss, because there has been a company that will bear all of that according to the agreement made beforehand.

The beginning of the establishment of Islamic insurance in Indonesia began in 1994 which was marked by the establishment of one of the Islamic insurance companies, namely Takaful Sharia Insurance initiated by the Association of Indonesian Muslim Intellectuals (ICMI) through the Abdi Bangsa Foundation, Bank Muamalat Indonesia, PT Asuransi Jiwa Tugu Mandiri, Ministry of Finance Indonesia, as well as several Indonesian Muslim entrepreneurs. Islamic insurance began operating officially the insurance 
operational license obtained from the Ministry of Finance through Decree No. Kep385/KMK.017/1994. Establishment of Islamic insurance is the implementation of Islamic values contained in the Al-Qur'an and Al-Sunnah, as well as the opinions of scholars or jurists contained in their works.

Islamic insurance companies in Indonesia grow along with the sharia-compliant financial institutions. This can be supported by a very large number of Muslim populations in Indonesia which makes the potential for the development of Islamic economics more real. This can be seen from the data published by the Financial Services Authority (OJK) in 2015, currently there are 53 Islamic insurance companies consisting of 24 sharia life insurance ( 5 full fledges and 19 sharia business units), 26 sharia general insurance ( 3 full fledges and 23 sharia business units), and 3 sharia reinsurance companies, all of which are sharia units. From the data published by the OJK in 2016, there was an increase in the number of sharia insurance consisting of 27 sharia general insurance companies $(6$ full fledges and 21 sharia business units) and 28 sharia life insurance (4 full fledges and 24 sharia business units).

Islamic insurance itself has several indicators that can make the extent to which Islamic insurance develops. This can be seen from the contributions of participants who entered the Islamic insurance company and also from the investments made by the Islamic insurance company and the results of the investments made by the Islamic insurance company itself. Later in the Islamic insurance company, it can be seen whether the Islamic insurance company is experiencing profits or losses.

In the operational process, Islamic insurance companies cannot be separated from the application of the underwriting management function. Underwriting is the process of selecting risks and classifying them according to the level that can be borne by the company. Underwriting itself has the intention of maximizing the profit gained through the acceptance of risk distribution which is expected to bring profit, without efficient underwriting, Islamic insurance companies will not be able to compete with conventional insurance (Darmawi, 2004: 31-32).

Tabarru fund underwriting is one of the important things that must be considered by Islamic insurance companies, because underwriting is a benchmark that can show how the Islamic insurance company manages participant funds. If the underwriting results are high, the company is good at managing participant funds, and vice versa if the underwriting results are low, the sharia insurance company is bad in managing the participants' funds (Fikri: 2009).

Underwriting, which is managed by an Islamic insurance company, may experience a surplus or deficit depending on how to manage it. Tabarru fund surplus underwriting 
is obtained from a pool of participant funds invested, then reduced by insurance costs or expenses such as claims and reinsurance (Sula, 2004: 180). Tabarru funds will experience a surplus if the contribution is greater than the number of claims and vice versa will experience a deficit if the number of claims is more than the total contribution of participants.

Surplus underwriting of tabarru fund itself is very important for Islamic insurance companies. In addition to showing the level of good tabarru fund management carried out by insurance companies to get a surplus, the surplus can also be divided between the participants and the company as the manager in accordance with the agreed ratio at the beginning of the contract.

According to the DSN MUI fatwa No. 53/DSN-MUI/III2006 concerning Tabarru agreement on Islamic insurance, if there is a tabarru fund surplus underwriting, then the following three alternatives can be done, namely:

1. Treated entirely as a backup fund in a tabarru account.

2. Partially saved as a reserve fund and distributed in part to participants who fulfill actuarial/ risk management requirements.

3. It is partially saved as a reserve fund and can be distributed in part to insurance companies and participants as long as the participants agree.

Factors influencing the surplus/ deficit underwriting of tabarru fund include contributions, claims, and investment returns. The surplus/ deficit underwriting is directly related to the three variables (Damayanti: 2016)

Based on the theories described above about the factors that influence surplus (deficit) underwriting of tabarru fund, the author intends to examine the independent variables including Participant Contributions, Claims, Net Investment and Retakaful Revenues. These four variables will be examined to find out which of these variables have the most influence on the dependent variable, while the dependent variable is the Islamic general insurance surplus underwriting in Indonesia within 2012-2016 periods.

This research is very important because when the insurance obtains a surplus underwriting, the fund can be used as a reserve for the payment of insurance claims in the future. It can also increase public confidence in the use of Islamic general insurance services. From increasing public trust in the use of Islamic general insurance services, it will make Islamic insurance grow rapidly so that it can compete with conventional insurance. Based on this rationale the author is interested to study entitled "The Influence of Participants' Contributions, Claims, Net Investment Income, and Retakaful to the 
Surplus Underwriting in Indonesia for the period 2012-2016." Based on the background description above, the researcher formulates the following research problems:

1. Do the participants' contribution, claim, net investment income and retakaful simultaneously influence the general Islamic insurance's surplus underwriting?

2. Do the participants' contribution, claim, net investment income and retakaful partially influence the general Islamic insurance's surplus underwriting?

The purposes of this research are:

1. Knowing the relationship of participants' contribution, claim, net investment income and retakaful to the general Islamic insurance surplus underwriting simultaneously.

2. Knowing the relationship of participants' contribution, claim, net investment income and retakaful to the general Islamic insurance surplus underwriting partially.

\section{Theoretical Basis}

In the Minister of Finance Regulation No.18/PMK.010/2010 Article 1 (one) that insurance based on sharia principles is:

"Mutual help (ta'awun) and protecting (takaful) efforts among the participants through the formation of a pool of funds (tabarru funds) managed according to sharia principles to face certain risks. Islamic insurance is also defined as a risk regulation that meets the requirements of sharia, mutual help, involving participants and operators."

According to the National Sharia Council of the Indonesian Ulema Council (DSN-MUI) which is contained in the fatwa of the National Sharia Council No. 21/DSNMUI/X/2001 Islamic insurance is

"efforts to protect and help each other among a number of people or parties through investments in the form of assets and or tabarru which provide a pattern of return to face certain risks through a contract (engagement) that is in accordance with sharia."

The difference between Islamic insurance and conventional insurance is that conventional insurance adheres to the concept of an agreement between two or more parties, whereby the insurer binds itself to the insured, by accepting an insurance premium, to provide a replacement to the insured, namely prioritizing profits. While the concept of sharia insurance adheres to the concept of a group of people who help each other, 
guarantee each other, and cooperate, in each way they issue tabarru funds. That is prioritizing cooperation to help others.

In takaful insurance in addition to helping each other, mutual guarantee, and cooperation there is also a sense of mutual responsibility. Based on the type of risk they bear, Islamic insurance is divided into two, namely family takaful and general takaful:

1. General takaful is a form of takaful that provides protection in the face of disasters or accidents on the property of participants.

2. Family takaful is a form of takaful that provides protection in the face of death and accidents on takaful participants.

In general, the contract in the concept of Islamic insurance is a tijarah contract and also a tabarru contract. The tijarah contract used is a mudharabah contract, while the tabarru contract used is a grant. In the Tijarah contract, the Islamic insurance company acts as a mudarib who manages funds from participants, while participants act as shahibul maal. While in the tabarru contract, the Takaful participant provides a grant that is used to help other participants affected by the disaster, while the company acts as a fund manager (Huda, 2010: 181).

In the contract concept used by Islamic insurance, it must use the principle in accordance with sharia based on the Qur'an and Hadith and can see the opinions of the Ulema/ scholars.

According to Sula (2004: 246), contribution (al-Musahamah) is a form of mutual cooperation where each participant contributes funds to a company and the participant is entitled to compensation for his contribution based on the amount of shares (premiums) he has (pays).

In the Statement of Financial Accounting Standards (PSAK) 108 paragraph 3, participant contributions are recognized as part of tabarru funds in participant funds. Participant funds consist of tabarru funds, investment funds, investment returns, and reserves of surplus underwriting. This is different from conventional insurance where the participant contribution (premium) is income for insurance companies, considering the contract is buying and selling, while in Islamic insurance the participant's contribution belongs to the participants themselves, considering the participants are willing to share risks to them.

According to Sula (2004: 259), claims are applications by participants to obtain coverage for losses available under the agreement. While claims are a process to get their rights to be fully respected as they should. 
Net Investment Income is the result of net investment in Tabarru funds carried out by Islamic insurance companies.

According to the DSN MUI fatwa No.53/DSN-MUI/III/2006 concerning tabarru contract on sharia insurance that investment from tabarru funds is the collective right of participants and recorded in a tabarru account. From investment income, insurance companies can obtain profit sharing based on mudharabah agreement or musharakah agreement, or obtain ujrah based on the wakalah bil ujrah contract.

Reinsurance in Islamic insurance is called a Retakaful. Retakaful is the process of sharing between the session giver and the guarantor with the same liking process, from various risks and requirements set forth in the contract known as the sharing of risk concept.

In the Financial Services Authority Regulation Number 23 / POJK 05/2015, the surplus underwriting is the surplus difference in the total participant contributions into the tabarru fund plus an increase in retakaful assets after deducting compensation payments/ claims, retakaful contributions and an increase in technical reserves, within a certain period.

\subsection{Inter-variable relationships}

\section{The relationship between participant contributions and surplus underwriting}

Contributions in Islamic insurance are part of the premium which in the context of this study is a portion of the premium allocated to tabarru funds. The term contribution is used because the fund is a contribution from the participants for the portion of risk and ujrah. In other words, the participant's contribution is the initial funds from the participants which have not been reduced by the expenses in the agreement and will automatically affect the surplus underwriting.

\section{The relationship between claims and surplus underwriting}

The claim is the participant's right and the funds are taken from tabarru funds. Claims are deductions from tabarru funds. So that when the number of claims increases the surplus underwriting decreases and vice versa; when the number of claims dcreases, it will increase the surplus underwriting of tabarru funds (Sula 2004: 260). In other words, the funds contained in the company will be issued if there are participants who submit claims at any time and will automatically affect the surplus underwriting that will be obtained.

\section{The relationship between net investment income and surplus underwriting}


Islamic insurance companies receive a number of funds from insurance participants. The funds are then invested in order to carry out the mandate and gain profits. Investment activities are considered important because one of the sources of profit for the company is derived from ujrah and profit sharing from investments.

\section{The relationship between retakaful and surplus underwriting}

Retakaful allows tabarru funds to be protected if there are claims that exceed the capacity that can result in tabarru fund deficits. That way the insurer will get the help of claim payments from the retakaful party so the insurer does not need to issue tabarru funds for claim payments. Automatic retakaful or reinsurance will affect the surplus underwriting.

Based on the background, the formulation of the problem, the purpose of the research, the theoretical basis that has been proposed, the hypotheses in this study are:

1. Participants' contributions, claims, net investment income and retakaful partially have a significant effect on the general Islamic insurance surplus underwriting in Indonesia.

2. Participants' contributions, claims, net investment income and retakaful simultaneously have a significant effect on the general Islamic insurance surplus underwriting in Indonesia.

\section{Methodology}

\subsection{Research approach}

The approach used in this study is quantitative approach. Quantitative analysis tools used in this study is panel data regression.

\subsection{Dependent variable}

\section{Surplus Underwriting}

Surplus Underwriting is the result of the participants' tabarru funds reduced by the total number of claims that occur (expenses); if the result of the reduction are positive then the company will experience a surplus, if the result of the reduction are negative, then the company will experience a deficit. Data is nominal data from the financial statetement of general Islamic insurance companies within 2012-2016. 


\subsection{Independent variable}

\section{Participants Contribution}

Participant contribution (X1) is a form of mutual cooperation where each participant contributes funds to a company and the participant is entitled to receive compensation for his contribution based on the amount of shares (premium) he has (pays). Participant contributions are recognized as part of tabarru funds. This study uses data of Gross Contribution on tabarru fund surplus underwriting reports. Data is nominal data from the financial statements of general Islamic insurance companies from 2012-2016.

2. Claim

Claim (X2) is an insurance participant's right that must be given by an insurance company in accordance with the agreement in the contract. Claims can be made when insurance participants experience a disaster. Payment of claims on sharia insurance is taken from tabarru funds. This study uses claim payment data on tabarru fund surplus underwriting reports. Data is nominal data from the financial statements of general Islamic insurance companies from 2012-2016.

3. Net Investment Income

Net Investment Income (X3) is the result of net investment in tabarru funds carried out by Islamic insurance companies. This study uses data on net investment income in the tabarru fund surplus underwriting report. Data is nominal data from the financial statements of general Islamic insurance companies from 2012-2016.

\section{Retakaful}

Retakaful (X4) is a part of tabarru funds that are issued to pay contributions to the reinsurer in order to share risks. This study uses reatakaful data on tabarru fund surplus underwriting report. Data is nominal data from the financial statements of general Islamic insurance companies from 2012-2016.

\subsection{Type and source of data}

The type of data in this study is panel data, which is a combination of time series data and cross section data. In this study the type of data used is secondary data.

The data used in this study uses financial data obtained from the financial statements of general Islamic insurance companies from 2012-2016 which were downloaded from the company's official website. 


\subsection{Population and sample}

The population used in this study is a general Islamic insurance company in Indonesia that has been registered with the Financial Services Authority during the period of 2012-2016.

The consideration taken in determining the sample in this study is to use a sample of general Islamic insurance companies and sharia units of general insurance companies in Indonesia whose financial statements are published and according to the required qualifications. Thus the data that has fulfilled as many as 40 data, with a sample of 8 companies by conducting research on general insurance companies namely 1 (one) general Islamic insurance company and 7 sharia units of general insurance companies in the period 2012 to 2016.

\subsection{Analysis technique}

The approach used in the research is a quantitative approach, which analyzes the measurement of economic phenomena which is a combination of economic theory (financial statement information) and statistical models classified in certain categories using tables to simplify the analysis using the program Eviews 9.0.

\section{Panel Data Regression}

Panel data analysis serves to combine information from time series data and cross sections can overcome problems that arise when there is an omitted variable problem (Widarjono, 2007: 249). To overcome the intercorrelations between independent variables that result in the misinterpretation of regression, the panel data method is more appropriate to use (Griffith, 2001: 351).

\section{Result and Discussion}

By analyzing the panel data regression test which is carried out based on the results of the Hausman test, the best model for this research is Fixed Effect Model (FEM), so that the probability value is presented in Table 1 as follows:

It is known that the F-test value of 8,600732 produces a probability value (significance value) of 0.000002 . Due to the probability value of $0.000001<0.05$, the decision taken is to reject $\mathrm{HO}$. These results conclude that the variables of participant contributions, claims, net investment income and retakaful simultaneously have a significant effect on the surplus underwriting. 
TABLE 1: Fixed Effect Model (FEM) Test Result.

\begin{tabular}{l|c|c|c|c}
\hline Variable & Coefficient & Std. Error & t-Statistic & Prob. \\
\hline C & $-2.58 \mathrm{E}+09$ & $2.76 \mathrm{E}+09$ & -0.934190 & 0.3582 \\
\hline KONTRIBUSI? & 0.179468 & 0.049426 & 3.631063 & 0.0011 \\
\hline KLAIM? & -0.379979 & 0.130876 & -2.903349 & 0.0071 \\
\hline INVEST? & 3.938342 & 1.156884 & 3.404267 & 0.0020 \\
\hline RETAKAFUL? & -0.142953 & 0.309765 & -0.461489 & 0.6480 \\
\hline & & Effects Specification & \\
\hline Cross-section fixed (dummy variables) & & & \\
\hline R-squared & 0.771630 & Mean dependent var & $8.18 \mathrm{E}+09$ \\
\hline Adj R-squared & 0.681913 & S.D. dependent var & $9.75 \mathrm{E}+09$ \\
\hline S.E. of regress & $5.50 \mathrm{E}+09$ & Akaike info criterion & 47.93752 \\
\hline Sum sq resid & $8.47 \mathrm{E}+20$ & Schwarz criterion & 48.44418 \\
\hline Log likelihood & -946.7503 & Hannan-Quinn criter. & 48.12071 \\
\hline F-statistic & 8.600732 & Durbin-Watson stat & 1.839920 \\
\hline Prob(F-stat) & 0.000002 & & \\
\hline
\end{tabular}

While based on the results of the $t$ test it can be concluded as follows:

\subsection{The influence of participants contribution on surplus under- writing}

The participant contribution variable was concluded partially having a significant effect on the surplus underwriting. This was decided by testing the probability value of 0.0011 which is smaller than 0.05 , meaning that $\mathrm{HO}$ is rejected and $\mathrm{H} 1$ is accepted. The direction of influence of the participant's contribution is positive which means that if the participant contribution has increased, the surplus underwriting value will also experience a significant increase.

\subsection{The influence of claim on surplus underwriting}

The claim variable is partially concluded to have a significant effect on the surplus underwriting. This was decided by testing the probability value of 0.0071 which is smaller than 0.05 , meaning that $\mathrm{HO}$ is rejected and $\mathrm{H} 1$ is accepted. The direction of the effect of the claim is negative which means if the claim has increased then the value of the surplus underwriting will experience a significant decrease. 


\subsection{The influence of investment income on surplus underwriting}

Variable of investment income is concluded partially has a significant effect on surplus underwriting. This was decided by testing the probability value of 0.0020 which is smaller than 0.05 , meaning that $\mathrm{HO}$ is rejected and $\mathrm{H} 1$ is accepted. The direction of influence of investment income is positive, which means that if investment income increases, the value of the surplus underwriting will also experience a significant increase.

\subsection{The influence of retakaful on surplus underwriting}

The retakaful variable is partially inferred that it has no significant effect on the surplus underwriting. This was decided by testing the probability value of 0.6480 which is greater than 0.05 meaning that $\mathrm{HO}$ is accepted and $\mathrm{H} 1$ is rejected. The direction of influence of a retakaful is negative which means that if a retakaful experiences an increase then the value of the surplus underwriting will decrease but tends to be insignificant (not large).

Based on the results of statistical testing with the best model, namely Fixed Effect Model (FEM), the R-Squared value is 0.771630 or $77.16 \%$. This figure shows that the variable surplus underwriting can be explained by the variable contribution of participants, claims, net investment income, and retakaful by $77.16 \%$. Large participant contributions, claims, net investment income, and retakaful on the general Islamic insurance surplus underwriting of $2012-2016$ that is equal to $77.16 \%$ and the remaining $22.84 \%$ is influenced by other factors not included in the study.

\section{Conclusion}

Based on the discussion of the results of research conducted on the effect of Participant Contributions, Claims, Net Investment Income, and Retakaful on Surplus Underwriting of Tabarru Fund on General Islamic Insurance Companies in Indonesia in 2012-2016, the conclusions of this study are:

1. Participant contribution partially has positive and significant influence, claim variable has negative and significant influence, variable of net investment income has a positive and significant effect, while the retakaful variable has no significant effect on the general insurance surplus underwriting in Indonesia at a significance of $\alpha 5 \%$ or 0.05 . 
2. Participant contributions, claims, net investment income, and retakaful simultaneously have a significant effect on the surplus underwriting of general Islamic insurance companies in Indonesia at $95 \%$ confidence level ( $\alpha 5 \%$ or 0.05 ).

3. Of the four independent variables examined, the most influential on the general Islamic insurance surplus underwriting in Indonesia within 2012-2016 is the Net Investment Income variable, with the largest coefficient of 3.938342.

\section{References}

[1] Damayanti, Febrinda Eka. 2016. Pengaruh Kontribusi Peserta, Klaim, dan Hasil Investasi terhadap Surplus Underwriting Asuransi Umum Syariah. Skripsi tidak diterbitkan. Universitas Airlangga.

[2] Darmawi, Herman. 2004. Manajemen Asuransi. Edisi pertama. Cetakan ketiga. Jakarta: PT Bumi Aksara.

[3] Departemen Agama Republik Indonesia. 2005. Al Qur’an dan Terjemahan. Bandung: Diponegoro

[4] Fatwa Dewan Syariah Nasional MUI No. 53/DSN-MUI/III/2006 tentang akad tabarru pada asuransi syariah.

[5] Fatwa Dewan Syariah Nasional MUI No. 21/DSNMUI/X/2001 tentang pedoman umum asuransi syariah,

[6] Fikri, M. Agung Ali. 2009. Pengaruh Premi, Klaim, Hasil Investasi dan Underwriting terhadap Laba Asuransi Jiwa (Studi Kasus PT Asuransi Syariah Mubarakah). Skripsi tidak diterbitkan. Institut Pertanian Bogor.

[7] Griffith, W.E. 2001. Undergraduate Econometrics.Cetakan kedua. Jhon Willey and Sons, Inc.

[8] Huda, Nurul. 2010. Lembaga Keuangan Is/am: Tinjauan Teoritis dan Praktik. Jakarta: Kencana Predana Media Group.

[9] Peraturan Menteri Keuangan No.18/PMK.010/2010 Tentang Prinsip Dasar Penyelenggaraan Usaha Asuransi dan Usaha Reasuransi dengan Prinsip Syariah.

[10] Rahman, Muh. Fudhail. 2011. Asuransi dalam perspektif hukum islam. al-'adalah Vol $X$, No. 1 Januari 2011

[11] Republik Indonesia. Undang-undang Nomer 2 Tahun 1992 tentang Usaha Perasuransian

[12] Sula, Muhammad Syakir. 2004. Asuransi Syariah (Life and General). Cetakan 1. Jakarta: Gema Insani Press. 
[13] Widarjono, Agus. 2013. Ekonometrika (Pengantar dan Aplikasinya). Edisi Keempat. Yogyakarta: UPP STIM YKPN. 